\title{
Prostate Cancer Awareness and Knowledge Among Men Residents in Al-Madinah Al-Munawarah, Saudi Arabia: A Surveillance Study
}

\section{Zakaria Eltahir*, Alahmadi E*, Mushal Alahmadi, Mohammed F Alahmadi and Moneira A Mansour}

Department of Medical Laboratory Technology, College of Applied Medical Science, Taibah University, Medinah, Saudi Arabia

*Corresponding Author: Zakaria Eltahir and Alahmadi E, Department of Medical Laboratory Technology, College of Applied Medical Science, Taibah University,

Medinah, Saudi Arabia.
Received: December 09, 2021

Published: January 10, 2022

(C) All rights are reserved by Zakaria Eltahir, Alahmadi E., et al.

\begin{abstract}
Background: Prostate cancer is a major health problem that affects a high percentage of populations on the local and global level, ranked globally as the fifth men cause of mortality. In Saudi Arabia prostate cancer incidence is estimated at about 6.6\%. Lack of knowledge about the disease and the nature of its routine clinical examination in any community can contribute to patients being arrived late to seek medical care. We have used scientific research engines to explore studies on prostate cancer that discuss and assess knowledge in our local community of Al-Madinah, unfortunately, no studies have been conducted in Al-Madinah region up to the time of conducting this work. Therefore, this study aimed to assess the awareness and knowledge of prostate cancer among the local population of Al-Madinah region.

Methodology: A cross-sectional study was conducted and self-designed questionnaire was generated and distributed containing multiple choice questions in order to asses and evaluate the level of awareness and knowledge among the population of Al-Madinah region. The IBM® SPSS $\AA$ software platform version no. 21.0 was used by applying the Chi-Square test in order to compare the multiple variables in the study.

Results: 502 participants have successfully completed the questionnaire. The results showed that $63 \%$ of the participants think that the prostate is a disease, $91 \%$ of the participants have never been examined by an urologist in their lifetime and $59 \%$ of the participants have obtained their information about the disease via internet.

Conclusion: The population of Al-Madinah region showed a moderate level of awareness on prostate cancer, but this level of knowledge has not been reflected the impact uptake of prostate cancer screening among participants. It is suggested that actions need be taken by the relevant authority to influence the uptake of prostate cancer screening in order to minimize the burden of the disease on the local community and probably within the whole country. Indeed, this will improve the quality of life and it would have a good reflection on the economy.
\end{abstract}

Keywords: Prostate Cancer; Awareness; Al-Madinah; Screening; Surveillance

\section{Introduction}

The lessons we have learned from the current global pandemic COVID-19 that general public worldwide, awareness and knowledge level of the scientific medical information can be affected by many factors, of which, would have a significant reflection on health care. Factors that could reflect on the national health care system would include the care quality provided and the availability of crucial and valuable information within communities. 
We should mention here that the relationship between the health care provider and the community is a crucial factor where they are complementary to each other. Early education, campaigns and medical programs could increase the basic knowledge of their local communities in relation to health problems that are common and could be prevented. Governments particularly represented by health authorities have a responsibility in protecting, promoting public wellbeing and providing the suitable knowledge for such serious illnesses. Prostate cancer is a major health problem among men in both developing and developed countries and it has a wide range of victims in each community, therefore, providing awareness about the disease should be handled more seriously. Prostate cancer is the second most common cause of death from cancer in men worldwide [1,2].

In Saudi Arabia, it is estimated that the prevalence of the disease is about $6.6 \%$ and it is expected to increase [3]. Lack of knowledge about the disease, its symptoms, complications and the nature of the routine prostate examination are major points that contribute into the patients' reach out for medical advice being seen at late stages of the disease [3]. We have used search engines to explore how the issue is been dealt with at our local community and there were no studies on awareness handling of the disease in the region of Al-Madinah Al-Munawarah in Saudi Arabia. Therefore, in this study we are aiming mainly to shed the light on the status of awareness of the disease among Al-Madinah male residents.

\section{Literature Review}

\section{Prostate cancer}

Prostate cancer is estimated as the second most common cancer affecting men worldwide and fifth most cause of cancer in both genders $[1,2]$. It can be defined as the cancer of the prostate gland, which is found only in men below the bladder in the pelvis area, lies in front of the rectum and around the urethra. The prostate gland is known for its share in the production of semen and its responsibility in carrying the sperm made by the testes. Prostate cancer is a frequent disease and is the second most cancer deaths causing in the United States [2]. Cancer cells are not named based on where they were detected in the body; they are named according to the origin of the organ that has the cancer cells emerged in the first place. The term metastasis can be defined as the process by which cancer cells spread to other organs via lymphatic system or blood stream. Prostate cancer mainly spread by lymphatic system into the bone and pelvis. Thus, when the cells of a prostate cancer origin spread to the lungs, it will not be named as lung cancer, but certainly it will be called a metastatic prostate cancer [5].

Prostate cancer initially may have no symptoms but in later stages several symptoms may appear such as the enlargement of the prostate gland, oliguria (weak urine stream), hematuria (blood in urine) and dysuria (urinary frequency) [6]. Other symptoms can develop when prostate cancer cells spread into other organs, these symptoms include weight loss, shortness of breath, bone pain, blood in the urine, burning urination, difficulty starting and stopping the urine stream, blood in semen, dribbling urine, erectile dysfunction, pelvic pain, painful ejaculation, low back pain, loss of control of urination when laughing or coughing and inability to urinate when standing [6].

There's no exact cause of prostate cancer, although it can be affected by several factors [7]. These factors include Age in which $60 \%$ of prostate cancer incidence occurs in older men over the age of 50, including rare cases in people under the age of 40 . Family history is considered also as a risk factor, in which a man whose father or brother (first-degree relative) has or had prostate cancer is twice as likely to develop the disease, it can run in families and the risk increases when a member of the family has the disease $[10,14]$. Race is also an important factor, in which the disease is less common in Asia, South and Central America, and it is more common in Europe (especially northwestern countries in Europe), North America, the Caribbean, and Australia, due to many factors like lifestyle and diet [2]. Indeed, the genetic factors can play a major role, as mutations in the cells' DNA will trigger the cell to become cancerous. Cancer occurs when genes that control the growth and death of a cell are affected which in turn might lead to abnormal growth or death of abnormal cells being disabled (apoptosis inactivated). In prostate cancer, it is estimated that $5-10 \%$ of prostate cancers are due to inherited mutated gene/s [12,21]. Several inherited genes can cause this, including RNASEL, BRCA-1, and BRCA-2, DNA mismatch genes, HPC1, and HoxB13 [14]. Other factors that contribute to the disease can include high intake of fatty foods (obesity) and red meats, as well as the low intake of vegetables and fruits which appear to be associated with increase the risk of developing prostate cancer. Sexual transmitted diseases (STDs), smoking and inflammation of the prostate gland may increase the risk of developing the disease $[14,20]$. 
In 2012, it was estimated that prostate cancer deaths are accounted for approximately 307,000 worldwide, which makes it the fifth leading cause of cancer death worldwide [13]. As seen in the figure below from International Agency for Research on Cancer, World Health Organization (WHO) (Figure 1); proportionally the mortality rates are higher in sub-Saharan Africa and in the Caribbean, intermediate in Oceana and Americas and low in Asia. On the other hand, the incidence rate is very high in most developed countries, in which Australia and New Zealand take the lead [11].

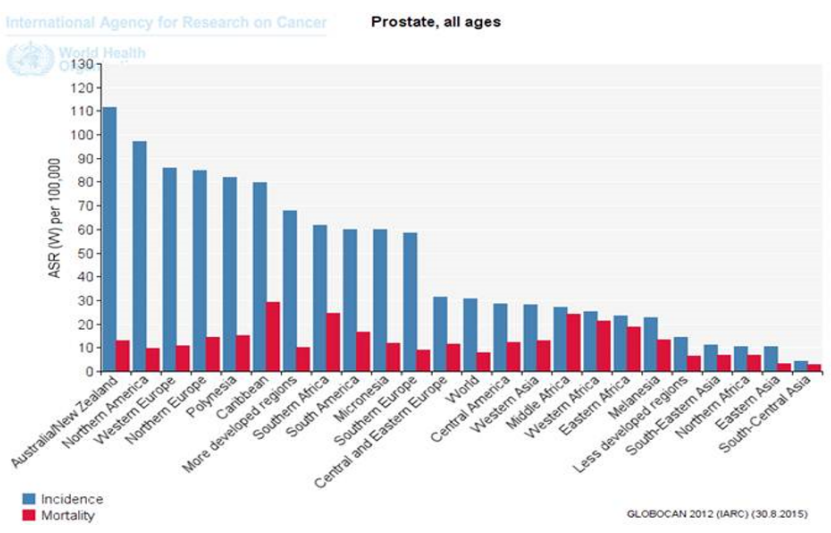

Figure 1: Age standardized incidence and mortality rate per 100,000 individuals in different parts of the world. Graph created by IARC data analysis software [11].

Incidence rate of prostate cancer in Saudi Arabia

In Saudi Arabia, it is estimated that prostate cancer incidence account for approximately $6.6 \%$ of the whole population [3]. As seen in the table below (Table 1, Age Standardized Incidence Rate (ASIR) was conducted in different parts of the country, in which the highest rates were seen in the Eastern region with a 10.1 ASIR followed by the capital city Al-Riyadh with a 7.1 ASIR and the lowest seen in Jazan with a 1.4 ASIR [14].

\section{Objectives and hypothesis of the study}

Our objectives are to determining prostate cancer awareness among the men population in Al-Madinah Al-Munawarah, Saudi Arabia. Indirect reflection on mortality rate and the health services costs in the percentage due to burdening the disease awareness.

\begin{tabular}{|l|c|}
\hline Saudi Arabia & ASIR per 100,000 men \\
\hline Asir & 3.7 \\
\hline Baha & 2.9 \\
\hline Jazan & 1.4 \\
\hline Madinah & 3.0 \\
\hline Hail & 2.1 \\
\hline Qassim & 2.6 \\
\hline Riyadh & 7.1 \\
\hline Makkah & 5.2 \\
\hline Najran & 2.0 \\
\hline Jouf & 4.2 \\
\hline Tabuk & 3.0 \\
\hline Eastern Region & 10.1 \\
\hline Northern Region & 3.9 \\
\hline
\end{tabular}

Table a: Age standardized incidence rate per 100,000 individuals in different regions in Saudi Arabia [14].

Our main research question: What is the level of awareness and knowledge on prostate cancer among men in Al-Madinah Al-Munawarah region?

Our hypothesis: Awareness and knowledge level on prostate cancer do not influence prostate cancer screening among men in Al-Madinah Al-Munawarah region. Specific factors such as age and education may have influence on the targeted population awareness and knowledge level of prostate cancer among men in Al-Madinah region, Saudi Arabia.

\section{Rationale of the study}

Numerous surveys have been used in various medical literatures to assess and analyze different aspects including those for healthcare awareness. In fact, these kinds of studies have changed healthcare policies and priorities in the developed countries. The numerous information and guidance they bring in to save lives, health authorities' budgets and sometimes lead to health management personnel consider new strategies benefiting from their outcomes.

A few studies in the literature looked into the prostate cancer focusing on population awareness among which study by Oranusi and his colleagues. Oranusi team conducted a prostate cancer awareness and screening among males of sub-Saharan population 
at Anambra state in Nigeria in 2012. Researcher's findings showed high level of awareness on the prostate cancer problem among local population and the screening test utilizing PSA blood test but they noticed a little number of the public servants have attended clinics to have the test done on them. The research team concluded their study by addressing the importance of the PSA screening and should be actively driven by healthcare providers employing the media and backed up by the National Health Authority policies [16]. Another study was conducted by Turkan along with his colleagues on the level of knowledge and awareness about prostate cancer and its effective relevant factors among Turkish men in 2016. The study findings showed lack of prostate screening among the sample participated in the study as well as the poor level of awareness and knowledge about prostate cancer. The researchers concluded that prostate cancer affects the male population over a certain age group with higher prevalence and mortality rate. They also stated different communities should increase levels of awareness and knowledge about the disease as how a serious condition it is but yet, treatable if diagnosed at early stage [15].

There were two studies at least in literature that were carried out in Saudi Arabia. The first study was carried out by Ahmed R. AlFarhan along with his team which conducted a research for the prostate cancer awareness among men in Eastern, Saudi Arabia in 2017. The team findings showed evidence of a weak level of knowledge and awareness about prostate cancer as well as its screening. The team concluded that these low levels reported can contribute to increase prevalence of the disease [3]. Another study focusing on Awareness of Prostate Cancer and Screening has been conducted by Ahmed Mousa Almuhanna and his colleagues recently among the male population at Riyadh region in Saudi Arabia in 2018. Researchers' findings showed that the majority of the participants have a high level of knowledge about prostate cancer, however, only minority of them have knowledge about the symptoms of prostate cancer and has undergoes regular screening for prostate cancer [17].

However, there was not a single study in the literature that was conducted in Al-Madinah area. Therefore, we are conducting this study to shed light on the status of the problem at our local community and as part of our responsibility as one of our university main roles is the service and development of the community.

\section{Methods, population and statistics}

\section{Study design}

The study design is a cross-sectional type which is an observational design. We have chosen this study design type specifically because it provides valuable information about the prevalence and association between the variables, as well as its usefulness in public health planning, monitoring and evaluation.

\section{Study area and targeted population}

This study took place in Al-Madinah Al-Munawarah region, Saudi Arabia; study population target was the male resident of AlMadinah region, Saudi Arabia.

\section{Inclusion and exclusion criteria}

Only male residents of Al-Madinah region, Saudi Arabia who are 21 years old and above are accepted in this study. Exclusion criteria includes being a female, or a male below 21 years and those who lives outside the Al-Madinah region.

\section{Questionnaire specification}

Self-designed questionnaires were made specifically to measure the awareness of the targeted population of Al-Madinah AlMunawarah region. The questionnaire started off by consenting participants for a voluntary acceptance and agreement for participation on the study, and researchers shall not reveal any personal private information about the participant. The study also included questions about the demographic data and multiple-choice questions about basic facts of the prostate gland and prostate cancer to reveal the general understanding of the targeted population on the gland and the cancer disease associated with. Age was considered a significant factor for being a potential risk that increases the chance of developing the disease. Since the targeted populations are native Arabic speakers, the questionnaire was prepared in Arabic to make it easier to understand questions. Implementing the technology and its benefits of reaching out for our targeted populations in most cases an electronic version was created and distributed. A website called survey monkey was used to generate and design a survey to suit our objectives on the questionnaire contents and concepts of the study. The questionnaire was distributed around the city using social media apps such as WhatsApp, Twitter, Snapchat and Emails, to the targeted populations, as participants were out of the region or less than 21 years old or a female, the system will not proceed and closes by initial disqualifying answers. 


\section{Study limitations}

Unfortunately, the outbreak of the pandemic COVID-19 has limited us from reaching out for the ultimate target number of participants and has obstructed us from having face to face contact with participants indeed those who are over the 60yrs age as more likely our electronic questionnaire wouldn't have reached out for them as an important targeted group.

\section{Ethical consideration}

Ethical approval for this study was obtained from the college of applied medical science, Taibah university in Al-Madinah AlMunawarh, Saudi Arabia (Project Ethical Certificate no. [SREC/ AMS 2020/51/CLD]. Participation in this study was voluntary and confidentiality was maintained throughout the research process.

\section{Statistical analysis}

The IBM $®$ SPSS $®$ software platform version no. 21.0 was used to generate statistical analysis by applying the Chi-Square test in order to compare the multiple variables in the study and P-value less than 0.05 was considered as a significant difference.

\section{Results}

\begin{tabular}{|l|c|c|}
\hline Variable & Number & Frequency \\
\hline Age & & \\
$21-30$ & 327 & $65.53 \%$ \\
$31-40$ & 70 & $14.03 \%$ \\
$41-50$ & 58 & $11.62 \%$ \\
$51-60$ & 30 & $6.01 \%$ \\
Above 60 & 14 & $2.81 \%$ \\
\hline Status & & \\
Student & 277 & $55.51 \%$ \\
Worker & 167 & $33.47 \%$ \\
Retired & 29 & $5.81 \%$ \\
Non-worker & 26 & $5.21 \%$ \\
\hline Education level & & \\
Primary school & 1 & $0.20 \%$ \\
Middle school & 9 & $1.80 \%$ \\
High school & 104 & $20.76 \%$ \\
Diploma & 54 & $10.78 \%$ \\
Bachelor & 284 & $56.69 \%$ \\
Higher education & 49 & $9.78 \%$ \\
\hline Occupation & & \\
Private sector & 76 & $30.40 \%$ \\
Military sector & 23 & $23.20 \%$ \\
Educational & 93 & \\
sector & 58 & \\
Health sector & & \\
\hline
\end{tabular}

Table 1: Participants Individual Parameters Distribution.

\begin{tabular}{|c|c|c|c|c|c|}
\hline \multirow{2}{*}{\multicolumn{2}{|c|}{ Yes }} & \multicolumn{3}{|c|}{$\begin{array}{c}\text { Do you know that } 50 \% \\
\text { of men at risk of prostate } \\
\text { enlargement }\end{array}$} & \multirow{3}{*}{\begin{tabular}{|l} 
Total \\
328 \\
\end{tabular}} \\
\hline & & \multirow{2}{*}{$\begin{array}{l}\text { No } \\
118 \\
\end{array}$} & \multirow{2}{*}{$\begin{array}{c}\begin{array}{c}\text { I don't } \\
\text { know }\end{array} \\
49 \\
\end{array}$} & \multirow[b]{2}{*}{161} & \\
\hline \multirow{5}{*}{$\begin{array}{l}\text { Age } \\
\text { group }\end{array}$} & $21-30$ & & & & \\
\hline & $31-40$ & 28 & 20 & 24 & 72 \\
\hline & $41-50$ & 27 & 14 & 17 & 58 \\
\hline & $51-60$ & 21 & 6 & 3 & 30 \\
\hline & More than 60 & 7 & 2 & 5 & 14 \\
\hline \multicolumn{2}{|r|}{ Total } & 201 & 91 & 210 & 502 \\
\hline
\end{tabular}

Table 2: Question of Prostate Benign hyperplasia knowledge, Do you think that $50 \%$ of men are at risk of prostate enlargement?

\begin{tabular}{|l|c|c|c|}
\hline & Yes & No & I don't know \\
\hline $\begin{array}{l}\text { Does "prostate" } \\
\text { mean a disease? }\end{array}$ & $316(63.2 \%)$ & $111(22.2 \%)$ & $73(13.6 \%)$ \\
\hline $\begin{array}{l}\text { Have you ever } \\
\text { been seen by a } \\
\text { urologist doctor } \\
\text { to check your } \\
\text { prostate? }\end{array}$ & $41(8.22 \%)$ & $458(91.78 \%)$ & \\
\hline $\begin{array}{l}\text { Do you know } \\
\text { that } 50 \% \text { of } \\
\text { men are at risk } \\
\text { of prostate } \\
\text { enlargement? }\end{array}$ & $200(40 \%)$ & $90(18 \%)$ & $210(42 \%)$ \\
\hline $\begin{array}{l}\text { Do you think } \\
\text { that prostate } \\
\text { cancer is an } \\
\text { infectious } \\
\text { disease? }\end{array}$ & $12(2.4 \%)$ & $396(79.04 \%)$ & $93(18.56 \%)$ \\
\hline $\begin{array}{l}\text { Do you think } \\
\text { that prostate } \\
\text { cancer could be } \\
\text { passed on to the } \\
\text { next generation } \\
\text { genetically? }\end{array}$ & $192(38.32 \%)$ & $134(26.75 \%)$ & $175(34.93 \%)$ \\
\hline $\begin{array}{l}\text { Do you have any } \\
\text { relatives that } \\
\text { were diagnosed } \\
\text { with prostate } \\
\text { cancer? }\end{array}$ & $51(10.2 \%)$ & $338(67.6 \%)$ & $111(22.2)$ \\
\hline $\begin{array}{l}\text { Do you know if } \\
\text { age is a risk } \\
\text { factor for } \\
\text { prostate cancer? }\end{array}$ & $326(65.46 \%)$ & $64(12.85 \%)$ & $108(21.69 \%)$ \\
\hline
\end{tabular}




\begin{tabular}{|l|l|l|l|}
\hline $\begin{array}{l}\text { Do you agree } \\
\text { to give a blood } \\
\text { sample } \\
\text { periodically if } \\
\text { this would make } \\
\text { you avoid this } \\
\text { disease? }\end{array}$ & $413(82.77 \%)$ & $86(17.23 \%)$ & - \\
\hline $\begin{array}{l}\text { Are you } \\
\text { prepared to take } \\
\text { a clinical } \\
\text { prostate } \\
\text { examination if } \\
\text { needed? }\end{array}$ & $298(59.84 \%)$ & $200(40.16 \%)$ & \\
\hline $\begin{array}{l}\text { Do you know if } \\
\text { an early } \\
\text { diagnosis would } \\
\text { help in giving a } \\
\text { good chance to } \\
\text { cure prostate } \\
\text { cancer? }\end{array}$ & $450(90.36 \%)$ & $10(2.01 \%)$ & $38(7.36 \%)$ \\
\hline
\end{tabular}

Table 3: General prostate illness knowledge questions [Yes, No, I don't know results].

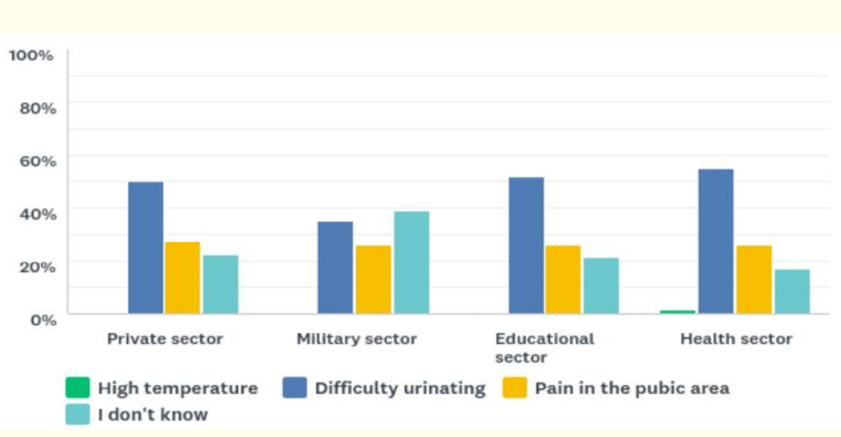

Figure 2: Comparison between Sectors Answers Regarding Question 8: which of the following do you think is an early sign of PCa?

\begin{tabular}{|l|c|c|}
\hline Variable & Number & Frequency \\
\hline Which of the following do you think is & & \\
an early sign of prostate cancer? & & \\
High temperature & 3 & $0.6 \%$ \\
Difficulty urinating & 247 & $49.4 \%$ \\
Pain in the pubic area & 136 & $27.2 \%$ \\
I don't know & 114 & $22.8 \%$ \\
\hline Which of the following samples might & & \\
help in the diagnosis of prostate & & \\
cancer? & & \\
Blood sample & 386 & $77.51 \%$ \\
Stool sample & 97 & $19.48 \%$ \\
Saliva sample & 7 & $1.41 \%$ \\
Hair traits & 8 & $1.61 \%$ \\
\hline
\end{tabular}

\begin{tabular}{|l|c|c|}
\hline When do you think you should check & & \\
your prostate? & 112 & $2.44 \%$ \\
After the age of 20 & 89 & $17.84 \%$ \\
After the age of 30 & 172 & $34.47 \%$ \\
After the age of 40 & 126 & $25.25 \%$ \\
After the age of 50 & & \\
\hline Which source of information helped & & \\
you to answer our questionnaire & & \\
today? & 293 & $59.19 \%$ \\
Internet & 35 & $7.07 \%$ \\
Books & 63 & $12.73 \%$ \\
Lectures & 104 & $21.01 \%$ \\
Social media &
\end{tabular}

Table 4: General prostate illness signs, symptoms and diagnosis knowledge questions.

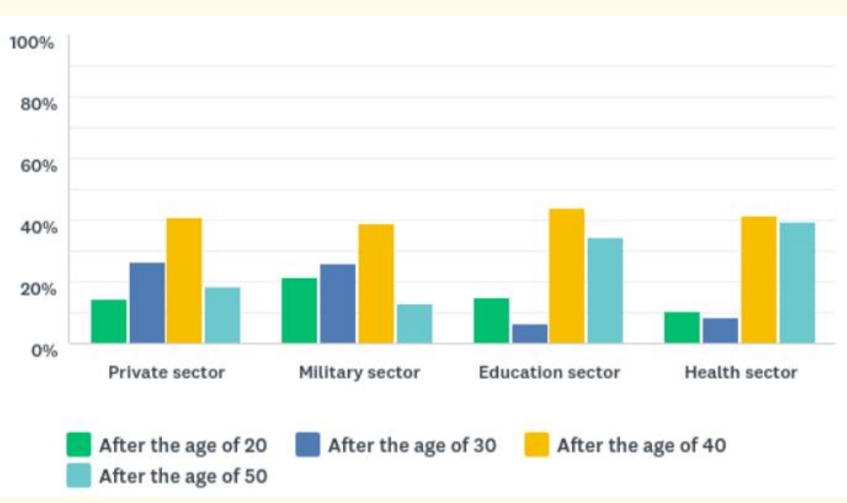

Figure 3: Comparison between Sector Answers Regarding Question 13: When do you think you should check your prostate?

\begin{tabular}{|l|c|c|c|}
\hline \multicolumn{4}{|c|}{ Chi-Square Tests } \\
\hline & Value & df & Asymp. Sig. (2-sided) \\
\hline $\begin{array}{l}\text { Pearson } \\
\text { Chi-Square }\end{array}$ & $30.864^{\mathrm{a}}$ & 8 & .000 \\
\hline Likelihood Ratio & 32.493 & 8 & .000 \\
\hline $\begin{array}{l}\text { Linear-by-Linear } \\
\text { Association }\end{array}$ & 17.922 & 1 & .000 \\
\hline N of Valid Cases & 502 & & \\
\hline
\end{tabular}

Table 5: Chi-Square test table in comparison between different age groups answers to question 3. 


\begin{tabular}{|c|c|c|c|c|c|}
\hline \multirow{2}{*}{\multicolumn{2}{|c|}{ Yes }} & \multicolumn{3}{|c|}{$\begin{array}{c}\text { Do you know that } \\
50 \% \text { of men at risk of } \\
\text { prostate enlargement }\end{array}$} & \multirow{3}{*}{\begin{tabular}{|c|} 
Total \\
1 \\
\end{tabular}} \\
\hline & & \multirow{2}{*}{$\begin{array}{c}\text { No } \\
1 \\
\end{array}$} & \multirow{2}{*}{$\begin{array}{c}\begin{array}{c}\text { I don't } \\
\text { know }\end{array} \\
0 \\
\end{array}$} & \multirow[b]{2}{*}{0} & \\
\hline \multirow{6}{*}{$\begin{array}{l}\text { Education } \\
\text { level }\end{array}$} & Primary school & & & & \\
\hline & Middle school & 4 & 2 & 3 & 9 \\
\hline & $\begin{array}{c}\text { Secondary } \\
\text { school }\end{array}$ & 41 & 17 & 46 & 104 \\
\hline & Diploma & 17 & 8 & 28 & 53 \\
\hline & BSC & 112 & 49 & 124 & 285 \\
\hline & $\begin{array}{c}\text { Higher } \\
\text { education }\end{array}$ & 26 & 15 & 9 & 50 \\
\hline \multicolumn{2}{|c|}{ Total } & 201 & 91 & 210 & 502 \\
\hline
\end{tabular}

Table 6: Education level of respondent's participants.

\begin{tabular}{|l|c|c|c|}
\hline & Value & DF & $\begin{array}{c}\text { Asymp. Sig. } \\
\text { (2-sided) }\end{array}$ \\
\hline Pearson Chi-Square & $17.587^{\mathrm{a}}$ & 10 & .062 \\
\hline Likelihood Ratio & 18.949 & 10 & .041 \\
\hline $\begin{array}{l}\text { Linear-by-Linear } \\
\text { Association }\end{array}$ & 1.736 & 1 & .188 \\
\hline No. of Valid Cases & 502 & & \\
\hline
\end{tabular}

Table 7: Chi-Square Tests; 6 cells (33.3\%) have expected count less than 5 . The minimum expected count is 18 .

A total of 502 male participants have completed the questionnaire with a mean age of 32 years. The highest percentage of the participants were those between the age of [21 to 30] (65.53\%) and the lowest were those who were above the age of [60] (2.81\%). Personal information for analysis usage have been collected shown the majority of the participants being students [277] (55.51\%) mostly with a Bachelor degree [284] (56.69\%). Also, a high percentage of the participants were workers working in different sectors; private [76] (30.4\%), military [23] (9.2\%), Educational [93] (37.2\%) and health [58] (23.2\%).

In regards to the "Yes", "No" and "I don't know" questions [presented in table 3] when participants were asked about if prostate is a disease, [316] (63.2\%) said "Yes" while [111] (22.2\%) said "No" and [37] (14.6\%) said that they don't know. When asked about if they have their prostate gland been checked at an urologist clin- ic before, a massive percentage of participants said "No" [458] (91.78\%) and [41] (8.22\%) said "Yes". When asked about if 50\% of men are at risk of prostate enlargement, participants answered with "Yes" [200] (40\%), "No" [90] (18\%) and "I don't know" [210] (42\%). When asked about if prostate cancer is an infectious disease, majority of the participants did not agree with this statement [396] (79.04\%) while a small portion said "Yes" [12] (2.4\%) and the rest said that "they don't know" [93] (18.56\%). However when asked of prostate cancer can be passed on genetically, [192] (38.32\%) said "Yes" while [134] (26.75\%) and a significant number said "I don't know" [175] (34.93\%). Most of the participants had no relatives that were diagnosed with prostate cancer [338] $(67.6 \%)$ while some of them had [51] (10.2\%).

When asked if age has part in increasing the chance of developing prostate cancer, participants answered with "Yes" [326] (65.46\%), "No" [64] (12.85\%) and "I don't know" [108] (21.69\%). When asked if they would give a blood sample periodically to avoid this disease, most of the participants said "Yes" [413] (82.77\%) while a small number said "No" [86] (17.23\%). On the other hand, when asked if they are willing to take a clinical prostate examination, participants surprisingly said "Yes" [298] (59.84\%) and the remaining participants said "No" [200] (40.16\%). When asked if an early diagnosis helps in treating prostate cancer, a massive portion of respondents said "Yes" [450] (90.36\%) and a few said "No" [10] (2.01\%) and the rest said they "don't know" [38] (7.63\%).

Analysis of the multiple-choice questions [presented in table 3] participants were asked to choose the right answer of what they think is correct from options provided for each question. When participants were asked which is an early sign of prostate cancer, they answered with high temperature [3] (0.60\%), difficulty urinating [247] (49.4\%), pain in the pubic area [136] (27.2\%) and the rest said that "they don't know" [114] (22.8\%). When asked which of the following is a way to diagnose prostate cancer, respondents answered with blood sample [386] (77.51\%), hair traits [8] (1.61\%), stool sample [97] (19.48\%) and a saliva sample [7] (1.41\%). A question towards the age of when prostate examination should be carried out the respondents answered with after 20 [112] (22.44\%), after 30 [89] (17.84\%), after 40 [172] (34.47\%) and after 50 [126] (25.25\%). Lastly, participants were asked about the source of their information the group answered from Internet were [293] (59.19\%), books [35] (7.07\%), lectures [63] (12.73\%) and from social media [104] (21.01\%) respectively. 


\section{Discussion}

Prostate cancer has been reported to be the fifth most diagnosed cancer in Saudi males in 2014, with an annual increasing frequency $[18,19]$. We have analyzed the data collected from the 502 participants who have responded to our invitation by completing our designated questionnaire that we have carefully prepared to fulfill our objectives stated for this study. Questionnaires were not fully completed or not meeting any of our inclusion criterion highlighted in the methodology of the study were considered as invalid and not taken in consideration. We found the overall prostate cancer knowledge and awareness among the screened population of Al-Madinah region is at a moderate level. We designed appropriate scientific questions that would identify the level of awareness with a mark in which if the majority of the population got the answer right, there will be a plus 1 mark. The survey included 9 actual scientific questions (Does "prostate" means a disease?/Do you know that $50 \%$ of men are at risk of prostate enlargement?/ Do you think that prostate cancer is an infectious disease?/Do you think that prostate cancer could be passed on to the next generation genetically ?/Do you know if age is a risk factor for prostate cancer?/Do you know if an early diagnosis would help in giving a good chance to cure prostate cancer?/Which of the following do you think is an early sign of prostate cancer?/Which of the following samples might help in the diagnosis of prostate cancer?/When do you think you should check your prostate?) And the majority of the population got 5 out of 9 marks (5/9). The awareness within the population has shown a significant difference between the different factors or variables within the study questions. Chi-square test that has been used to compare between different age groups and educational levels answers to question 3: Do you know that $50 \%$ of men are at risk of prostate enlargement? has presented a significant difference in the age groups in which P-value was < 0.05 , while on the other hand it showed no significant difference between educational levels as P-value was $>0.05$ while the likelihood ratio is $<0.05$. A percentage of a 63 of the participants didn't know what "the prostate" is, in which most of the population don't know that prostate is a gland in the first place. Certainly, this is a major concern for us as researchers and should be similarly to the local health authority and the community. First of all, Age had a significant role in influencing the level of awareness among the population in which the older the person is the higher the awareness level should be, here and specifically, about prostate cancer, the re- sults showed a gradual increase in awareness along age in the different groups involved in the study. Secondly, educational level has shown in this study a major role in the awareness increased level in which the results showed people with a higher education degree had more awareness than those only with a high school, diploma and even a bachelor's degree, and this proves again that the more educated the person is the more knowledgeable he would be.

Employees from different sectors where included in the study and as expected people from the health sector had more knowledge than those form the private, military and educational sector which can be interpreted as that the field that a person works in also have an influence on the level of awareness they might hold, such as, those in the medical field tend to have a quiet good background about health conditions such as the issue we are researching here the prostate cancer. Unfortunately, the study has highlighted a major concern that even the group of people who hold a higher level of awareness about the prostate cancer have failed to show their alliance and respect to medical facts and good precautions for a better lifestyle. This is unlike the general public and the less educated individuals. Of course, our study results showed the group of a well-educated and even heath sector practitioners among men in Al-Madinah region, who have participated in the study, have not been influenced by their knowledge and awareness to undertake a prostate cancer screening tests. This is despite, the various age groups were willing to take a clinical prostate examination, people between the age of 21-30 have a hard time accepting the examination which could be due to threatening their masculinity. However, an alternative approach could be followed in prostate cancer screening using blood tests (e.g., PSA) since the majority of participants have accepted to check their prostate health status as far as a blood testing method is welcomed. A large percentage (67.6\%) of the participants said that they don't have a relative who were diagnosed with prostate cancer which can be an indicator for the prevalence of prostate cancer among the population of Al-Madinah region. The answer by most of the participants to our last question about the source of information that helped them to answer our questionnaire was given as they have gained their knowledge about prostate cancer through related topics they come across on the internet (59.19\%).

Similar Studies conducted in Saudi Arabia have showed significant results compared to our findings, For example, A study in Riyadh observed that the number of participants who routinely 
undergo continuous PCa screening was very low but with a high level of knowledge and awareness [17]. Another study conducted by AlFarhan and colleagues in the Eastern region of Saudi Arabia has also showed low level of awareness and knowledge, as well as low level of PCa screening as most of the participant didn't underwent any PCa screening in the last two years [3]. These results have also been observed in our study as 91\% of the participants haven't checked their prostate at an urologist before, but the population in Madinah region actually showed a moderate level of awareness and knowledge about prostate cancer.

\section{Conclusion}

In conclusion, the male populations of Al-Madinah, Saudi Arabia have a moderate and a decent background on prostate cancer as compared to other studies from other parts of the Kingdom. Although This level of knowledge was at a good rate, unfortunately this doesn't reflect in the prostate cancer screening or being keen to prevent such disease among the majority of population participated on this study including healthcare workers as this shown only low number of the participants have sought of testing or checking their prostate at a specialist clinic before. Age and educational level have shown to influence the level of awareness.

\section{Bibliography}

1. Bray F., et al. "Global cancer statistics 2018: GLOBOCAN estimates of incidence and mortality worldwide for 36 cancers in 185 countries". CA: A Cancer Journal for Clinicians 68.6 (2018): 394-424.

2. Rawla P. "Epidemiology of Prostate Cancer". World Journal of Oncology 10.2 (2019): 63-89.

3. AlFarhan A., et al. "Prostate Cancer Awareness Among Male Population in Eastern Saudi Arabia". International Journal of Scientific Research 6.3 (2017).

4. Prostate Cancer-Patient Version (2019).

5. Ruddon R. “Cancer biology the 4th ed (2007).

6. Jameson J., et al. “Harrison's principles of internal medicine (2015).

7. Hsing A and Chokkalingam A. "Prostate cancer epidemiology". Frontiers in Bioscience 11.1 (2006): 1388.

8. Steinberg G., et al. "Family history and the risk of prostate cancer". The Prostate 17.4 (1990): 337-347.
9. Chemicals in Meat Cooked at High Temperatures and Cancer Risk (2019).

10. Inherited Risk for Prostate Cancer (2019).

11. Banerjee S and Kaviani A. "Worldwide Prostate Cancer Epidemiology: Differences Between Regions, Races, and Awareness Programs". International Journal of Clinical and Experimental Medical Sciences 2.1 (2016): 1.

12. Alghamdi I., et al. "The power of the age standardized incidence rate to discover the gene link between cancer diseases: development of a new epidemiological method to save money, time, and effort for genetic scientists". Oncotargets and Therapy (2015): 677.

13. International Agency for Research on Cancer. GLOBOCAN 2012: Cancer incidence and mortality worldwide in (2012).

14. Edge S., et al. "AJCC cancer staging manual (7th ed.). New York: Springer (2009).

15. Turkan S., et al. "The level of knowledge and awareness about prostate cancer in the Turkish male and the relevant effective factors". Türk Üroloji Dergisi/Turkish Journal Of Urology 42.3 (2016): 134-139.

16. Oranusi C., et al. "Prostate cancer awareness and screening among male public servants in Anambra State, Nigeria". African Journal of Urology 18.2 (2012): 72-74.

17. Almuhanna A., et al. "Awareness of Prostate Cancer, Screening and Methods of Managements in a Hospital in Riyadh, Saudi Arabia". The Egyptian Journal of Hospital Medicine 70.7 (2018): 1090-1092.

18. Yousef Mohammed Rabaa., et al. "Prostate Cancer and the Therapeutics challenges". Journal of Biological Research-Thessaloniki 27 (2020): 20.

19. Alghamidi IG., et al. "The incidence rate of prostate cancer in Saudi Arabia. An observational descriptive epidemiological analysis of data from the Saudi Cancer Registry 2001-2008". Hematology Oncology and Stem Cel 7 (2014): 18-26.

20. John E Niederhuber., et al. "Abeloff's clinical oncology". Philadelphia, PA: Elsevier (2020).

21. Marco Matejcic., et al. "Germline variation at 8q24 and prostate cancer risk in men of European ancestry". Nature Communications 9.1 (2018): 4616. 


\section{Assets from publication with us}

- Prompt Acknowledgement after receiving the article

- Thorough Double blinded peer review

- Rapid Publication

- Issue of Publication Certificate

- High visibility of your Published work

Website: www.actascientific.com/

Submit Article: www.actascientific.com/submission.php

Email us: editor@actascientific.com

Contact us: +91 9182824667 